\title{
Phosphorus use efficiency by maize cultivars for the production of green ears
}

\author{
Antônio F. Almeida ${ }^{1}$, Leilson C. Grangeiro ${ }^{1}$, Núbia M. Ferreira ${ }^{1}$, Victor E. de V. Gomes ${ }^{1}$, \\ Santiago A. Silva ${ }^{1} \&$ Rodolfo R. de A. Lacerda ${ }^{1}$ \\ ${ }^{1}$ Universidade Federal Rural do Semi-Árido/Centro de Ciências Agrárias/Departamento de Ciências Agronômica e Florestal. Mossoró, RN, Brasil. \\ E-mail: fabricioalmeida@ufersa.edu.br (Corresponding author) - ORCID: 0000-0002-6000-1924; leilson@ufersa.edu.br - ORCID: 0000-0002-4613-3605; \\ nubiamarisa1@hotmail.com- ORCID:0000-0001-7159-6479; v.e.de.v.gomes@gmail.com- ORCID:0000-0002-4598-7983; santiagoce2010@hotmail.com - ORCID: \\ 0000-0002-3203-3451; rodolfo-lacerda@hotmail.com - ORCID: 0000-0001-7067-0526
}

\begin{abstract}
The objective of this study was to evaluate the efficiency of the use of phosphorus by maize cultivars for the production of green ears. Two experiments were carried out, one in the rainy season (March to June) and the other in the dry period (August to December), both at the Rafael Fernandes Experimental Farm, in the community of Alagoinha, belonging to the Universidade Federal Rural do Semiárido, in the municipality of Mossoró, RN, Brazil. The treatments consisted of a combination of three levels of phosphorus (low, medium and high) and eight corn cultivars (Dona Josélia, Carrapateira, Pontinha, Cruzeta, Potiguar, BRS 2022, Status and AG 1051). A randomized block design was used in a $3 \times 8$ factorial scheme, with four repetitions. The evaluated characteristics were: number and total mass of green ears, number and mass of tradable, stuffed and depleted green ears, agronomic and physiological efficiency of production of recovery and use of phosphorus. The cultivars showed better productive performance when fertilized with phosphorus. The cultivars Cruzeta, Potiguar, BRS 2022, Status, AG 1051 and Carrapateira were the most efficient in the use of phosphorus to produce green maize.
\end{abstract}

Key words: Zea mays, productivity, mineral nutrition

\section{Eficiência do uso de fósforo por cultivares de milho visando a produção de espigas verdes}

RESUMO: Objetivou-se avaliar a eficiência da utilização de fósforo por cultivares de milho para produção de espigas verdes. Foram conduzidos dois experimentos, um no período chuvoso (março a junho) e outro no período seco (agosto a dezembro), ambos na Fazenda Experimental Rafael Fernandes, na comunidade de Alagoinha, pertencente à Universidade Federal Rural do Semiárido, no município de Mossoró, RN. Os tratamentos foram constituídos pela combinação de três níveis de fósforo (baixo, médio e alto) e oito cultivares de milho (Dona Josélia, Carrapateira, Pontinha, Cruzeta, Potiguar, BRS 2022, Status e AG 1051). Foi utilizado o delineamento experimental em blocos ao acaso, em esquema fatorial $3 \times 8$, com quatro repetições. As características avaliadas foram: número e massa total de espigas verde, número e massa de espigas verdes comercializáveis (empalhadas e despalhadas), eficiências agronômica, fisiológica, de produção de espigas, de recuperação e de utilização do fósforo. As cultivares apresentaram melhor desempenho produtivo quando adubadas com fósforo. As cultivares Cruzeta, Potiguar, BRS 2022, Status, AG 1051 e Carrapateira foram as mais eficientes na utilização do fósforo para a produção de milho verde.

Palavras-chave: Zea mays, produtividade, nutrição mineral 


\section{INTRODUCTION}

Maize (Zea mays L.) is the main cereal cultivated in the world, and Brazil is the third largest producer, where it is grown in all regions. It is mainly marketed in the form of grains, but in recent years the demand for green ears for fresh consumption has increased (Paiva et al., 2012; Corrêa Junior et al., 2014; Couto et al., 2017).

Factors related to soil fertility are among those that most contribute to the low yield of green ears in the Northeast region of Brazil, especially phosphorus (P), the third nutrient most required by the crop, considered one of the main nutrients that limit maize yield (Machado \& Souza, 2012; Oliveira et al., 2015).

The low rate of $\mathrm{P}$ utilization by maize suggests the use of large amounts in phosphate fertilization, which substantially increases the costs with this management practice (Gazola et al., 2013). In addition, global $\mathrm{P}$ stocks can be depleted within 300 years (USGS, 2019) and its excess in soil can cause environmental pollution, such as eutrophication of rivers and lakes (Klein \& Agne, 2012).

Several researchers have developed methodologies to evaluate the adaptation of maize to soils with low $\mathrm{P}$ availability (Sousa et al., 2012; Mendes et al., 2014; Meirelles et al., 2016; Colombo et al., 2018), highlighting that there are differences between maize genotypes regarding the ability to absorb and use the $\mathrm{P}$ available in soil.

The objective of this study was to evaluate the efficiency of $\mathrm{P}$ utilization by maize cultivars for the production of green ears.

\section{Material And Methods}

The experiments were carried out from March to July (season 1) and from August to December 2017 (season 2), at the Rafael Fernandes Experimental Farm, in the community of Alagoinha, belonging to the Universidade Federal Rural do Semiárido (UFERSA), in the municipality of Mossoró, RN, Brazil ( $5^{\circ} 11^{\prime \prime} \mathrm{S}$ and $37^{\circ} 20^{\prime \prime} \mathrm{W}$, with $18 \mathrm{~m}$ of altitude).

The climate of the region is semi-arid according to Thornthwaite, and BSwh', hot and dry, according to Köppen's classification, with average annual rainfall of $673.9 \mathrm{~mm}$, average temperature of $27^{\circ} \mathrm{C}$ and air relative humidity of $68.9 \%$, with two climatic seasons: a dry one, which usually occurs from June to January, and a rainy one, from February to May (Carmo Filho \& Oliveira, 1995).

The experiments were conducted in areas that were under spontaneous vegetation, not yet fertilized. The soil of the experimental areas was classified as Oxisol, of sandy loam texture and flat relief.

Before installing the experiments, composite soil samples were collected in the experimental areas at depths of $0-20 \mathrm{~cm}$ and $20-40 \mathrm{~cm}$, for chemical characterization and determination of clay content (Table 1).

Some climatic data were recorded along the experiments, as presented in Table 2 .

The treatments consisted of the combination of three levels of $\mathrm{P}$ (low, medium and high) and eight maize cultivars (Dona Josélia, Carrapateira, Pontinha, Cruzeta, Potiguar, BRS 2022, Status, AG 1051). The experimental design was randomized blocks in a $3 \times 8$ factorial scheme, with four repetitions.

Each experimental plot consisted of three rows with length of $3 \mathrm{~m}$, spaced apart by $0.8 \mathrm{~m}$, containing 10 plants in each row, considering as the usable area the central row, disregarding one plant on each end.

The three P levels were used to evaluate the efficiency of $\mathrm{P}$ use by maize cultivars. The low level corresponds to the original $\mathrm{P}$ content of the soil, while the medium and high levels correspond to the $\mathrm{P}_{2} \mathrm{O}_{5}$ doses of 40 and $80 \mathrm{~kg} \mathrm{ha}^{-1}$, that is, 50 and $100 \%$ of the dose recommended for maize, according to Cavalcanti (2008).

Table 1. Chemical attributes and soil clay content before the experiment, evaluated in the 0-20 and 20-40 cm layers, in two seasons

\begin{tabular}{|c|c|c|c|c|c|c|c|c|c|}
\hline \multirow{2}{*}{$\begin{array}{l}\text { Depth } \\
\text { (cm) }\end{array}$} & \multirow{2}{*}{ pH } & $\mathbf{P}$ & $\mathrm{K}$ & $\mathrm{Na}$ & $\mathrm{Ca}$ & $\mathrm{Mg}$ & Al & $(\mathrm{H}+\mathrm{Al})$ & \multirow{2}{*}{$\begin{array}{l}\text { Clay } \\
\text { (g kg }^{-1}\end{array}$} \\
\hline & & \multicolumn{3}{|c|}{$\left(\mathrm{mg} \mathrm{dm^{-3 } )}\right.$} & \multicolumn{4}{|c|}{$\left(\mathrm{cmol}_{\mathrm{c}} \mathrm{dm}^{-3}\right)$} & \\
\hline \multicolumn{10}{|c|}{ Season 1 (March to July, 2017) } \\
\hline $0-20$ & 5.00 & 0.1 & 35.5 & 8.8 & 0.40 & 0.60 & 0.05 & 1.16 & 153 \\
\hline $20-40$ & 4.40 & 0.1 & 34.5 & 4.8 & 0.20 & 0.50 & 0.15 & 1.32 & 244 \\
\hline \multicolumn{10}{|c|}{ Season 2 (August to December, 2017) } \\
\hline $0-20$ & 5.80 & 2.0 & 36.9 & 8.0 & 0.80 & 0.30 & 0.15 & 0.99 & 140 \\
\hline $20-40$ & 5.40 & 1.0 & 40.9 & 5.0 & 0.30 & 0.30 & 0.25 & 1.49 & 229 \\
\hline
\end{tabular}

Table 2. Climatological data of Mossoró, RN, Brazil, from March to December $2017^{1}$

\begin{tabular}{|c|c|c|c|c|c|c|c|}
\hline \multirow{2}{*}{ Month } & \multicolumn{3}{|c|}{ Temperature ( $\left.{ }^{\circ} \mathrm{C}\right)$} & \multirow{2}{*}{$\begin{array}{l}\text { Total global radiation } \\
\qquad\left(\mathrm{W} \mathrm{m}^{-2}\right)\end{array}$} & \multirow{2}{*}{$\begin{array}{l}\text { Accumulated precipitation } \\
\qquad(\mathrm{mm})\end{array}$} & \multicolumn{2}{|c|}{ Air relative humidity (\% } \\
\hline & Max & Mean & $\operatorname{Min}$ & & & Max. & Min. \\
\hline March & 36.04 & 27.24 & 22.49 & 225.83 & 137.00 & 98.10 & 44.50 \\
\hline April & 36.47 & 27.33 & 20.77 & 234.00 & 62.60 & 99.00 & 45.60 \\
\hline May & 38.64 & 27.97 & 19.39 & 226.38 & 15.40 & 98.00 & 31.90 \\
\hline June & 36.31 & 27.72 & 20.65 & 211.31 & 14.20 & 97.30 & 31.50 \\
\hline July & 35.64 & 26.99 & 19.10 & 198.87 & 58.60 & 98.20 & 29.30 \\
\hline August & 37.92 & 27.45 & 19.37 & 254.67 & 0.20 & 93.50 & 29.00 \\
\hline September & 38.45 & 27.96 & 19.56 & 263.64 & 2.40 & 90.80 & 24.50 \\
\hline October & 38.64 & 28.32 & 21.03 & 267.05 & 0.80 & 91.40 & 29.30 \\
\hline November & 37.15 & 28.04 & 20.96 & 277.66 & 0.60 & 91.50 & 32.90 \\
\hline December & 37.29 & 28.40 & 21.84 & 250.93 & 1.40 & 93.50 & 36.70 \\
\hline
\end{tabular}

${ }^{1}$ Data obtained in a semi-automatic weather station installed at Rafael Fernandes Experimental Farm, UFERSA; Max - Maximum; Min - Minimum 
Soil tillage was carried out with one plowing and one harrowing, followed by the opening of the furrows with approximately $0.20 \mathrm{~m}$ depth for basal fertilization, according to soil analysis and to the recommendation of Cavalcanti (2008) for maize: $30 \mathrm{~kg} \mathrm{ha}^{-1}$ of $\mathrm{N} ; 60 \mathrm{~kg} \mathrm{ha}^{-1}$ of $\mathrm{K}_{2} \mathrm{O} ; 1.0 \mathrm{~kg} \mathrm{ha}^{-1}$ of $\mathrm{B}$; $3.0 \mathrm{~kg} \mathrm{ha}^{-1}$ of $\mathrm{Zn}$ and $0.5 \mathrm{~kg} \mathrm{ha}^{-1}$ of $\mathrm{Cu}$, whereas $\mathrm{P}$ was applied according to the treatments.

The sources used were: urea, potassium chloride, boric acid, zinc sulfate, copper sulfate and triple superphosphate. Topdressing fertilization was performed by applying $30 \mathrm{~kg} \mathrm{ha}^{-1}$ of $\mathrm{N}$ at 15 days after emergence (DAE) and $30 \mathrm{~kg} \mathrm{ha}^{-1}$ of $\mathrm{N}$ when the plant had eight true leaves.

Sowing was performed on 03/16/2017 in Season 1 and on $08 / 24 / 2017$ in Season 2, with three seeds per pit, at $0.8 \times 0.3 \mathrm{~m}$ spacing, and thinning was carried out when the plants had four true leaves (nine days after sowing), leaving one plant per pit, in a total of 41,667 plants ha ${ }^{-1}$.

Irrigation was applied by a drip system, with emitters spaced by $0.3 \mathrm{~m}$ and flow rate of $1.4 \mathrm{~L} \mathrm{~h}^{-1}$. In Experiment 1 , irrigations were performed when necessary; a supplementary water depth of $388 \mathrm{~mm}$ was applied, as it rained $288 \mathrm{~mm}$ along this period. In Experiment 2, as there was virtually no rain (5.4 mm), a $664 \mathrm{~mm}$ water depth was applied.

Weed control, when necessary, was performed by manual weeding in the rows and using a hoe in the interrows. Four sprays were performed using the insecticides Decis ${ }^{\circledast}\left(200 \mathrm{~mL} \mathrm{ha}^{-1}\right)$ and Premio $^{\oplus}\left(100 \mathrm{~mL} \mathrm{ha}^{-1}\right)$ to control fall armyworm (Spodoptera frugiperda J. E. Smith).

Harvest was performed manually at the phenological stage R3 (milky grains) at 70 days after sowing (DAS), in both seasons, except for the cultivar Carrapateira, harvested at 85 DAS, in both seasons.

The numbers and yields of marketable unhusked green ears (ears with no evidence of pest or disease attack, $\geq 22 \mathrm{~cm}$ long) and marketable husked green ears (ears full of grains and $\geq 18 \mathrm{~cm}$ long) were determined.

Two plants per plot were divided into leaves, stem, roots and ears, separately placed in paper bags and dried in a forced air circulation oven at $65{ }^{\circ} \mathrm{C}$ until reaching constant weight.

$\mathrm{P}$ analysis was performed in extract obtained by sulfuric digestion of dry material samples. The $\mathrm{P}$ concentration in each extract was read using the molybdenum blue method (Malavolta et al., 1997).

$\mathrm{P}$ accumulation in each plant part was obtained through the product between the $\mathrm{P}$ concentration and the dry matter of the respective parts.

With the data of dry matter, $\mathrm{P}$ accumulation and yield of green ears, the following indices were calculated (Fageria, 2008): Agronomic efficiency (AE); Physiological efficiency (PE); Ear production efficiency (EPE); Recovery efficiency (RE) and Use efficiency (UE), using the following equations:

$$
\begin{gathered}
\mathrm{AE}\left(\mathrm{kg} \mathrm{kg}^{-1}\right)=\frac{(\mathrm{PEwP}-\mathrm{PEw} / \mathrm{oP})}{\mathrm{QPa}} \\
\mathrm{PE}\left(\mathrm{kg} \mathrm{kg}^{-1}\right)=\frac{(\mathrm{TDMwP}-\mathrm{TDMw} / \mathrm{oP})}{(\mathrm{PAwP}-\mathrm{PAw} / \mathrm{oP})}
\end{gathered}
$$

$$
\begin{gathered}
\operatorname{EPE}\left(\mathrm{kg} \mathrm{kg}^{-1}\right)=\frac{(\mathrm{PEwP}-\mathrm{PEw} / \mathrm{oP})}{(\mathrm{PAwP}-\mathrm{PAw} / \mathrm{oP})} \\
\operatorname{RE}\left(\mathrm{kg} \mathrm{kg}^{-1}\right)=\frac{(\mathrm{PAwP}-\mathrm{PAw} / \mathrm{oP})}{\mathrm{QPa}} \\
\mathrm{UE}\left(\mathrm{kg} \mathrm{kg}^{-1}\right)=\mathrm{PE} \mathrm{RE}
\end{gathered}
$$

where:

PEwP - production of greens ears with phosphate fertilization, kg;

PEw/oP - production of greens ears without phosphate fertilization, $\mathrm{kg}$;

$\mathrm{QPa}$ - quantity of $\mathrm{P}_{2} \mathrm{O}_{5}$ applied, kg;

TDMwP - total dry matter production with phosphate fertilization, $\mathrm{kg}$;

TDMw/oP - total dry matter production without phosphate fertilization, $\mathrm{kg}$;

PAwP - total P accumulation with phosphate fertilization, $\mathrm{kg}$; and,

PAw/oP - total P accumulation without phosphate fertilization, $\mathrm{kg}$.

The data were subjected to analysis of variance, and the means of $\mathrm{P}$ levels were compared by Tukey test, $\mathrm{p} \leq 0.05$, while the means of the cultivars were compared by Scott-Knot test, at $\mathrm{p} \leq 0.05$, using the statistical program SISVAR (Ferreira, 2011).

\section{Results AND Discussion}

In both seasons, there was a significant effect $(\mathrm{p} \leq 0.05)$ of the interaction between $P$ levels and cultivars for all variables. Plants in treatments that did not receive phosphate fertilization (low level of P) were stunted, with purplish color up to V3 stage (first three weeks) and high attractiveness to fall armyworm (Spodoptera frugiperda).

The total number of ears (TNE), number of marketable unhusked ears (NMUE), number of marketable husked ears (NMHE), total yield of ears (TYE), yield of marketable unhusked ears (YMUE) and yield of marketable husked ears (YMHE) increased with the increase in P levels (Tables 3, 4 and 5).

The cultivar BRS 2022 had higher TNE at all doses, followed by the cultivars Status, AG 1051 and Potiguar in Season 1. In Season 2, the cultivar Status was statistically superior to the others, followed by AG 1051 (Table 3).

By comparing the TNE of the environment without $\mathrm{P}$ application (low level of $\mathrm{P}$ ) with that of the environment with fertilization (medium and high levels of $\mathrm{P}$ ), it is possible to observe significant increments when phosphate fertilization was used; according to the overall mean, the highest level of P promoted increments of 41 and $38 \%$ compared to the lowest level of $\mathrm{P}$, in Seasons 1 and 2, respectively.

Likewise, NMUE and NMHE also increase with the application of $\mathrm{P}$ (Tables 3 and 4), i.e., maize crop responds very well to phosphate fertilization, mainly in terms of the production 
Table 3. Mean values for the total number of ears (TNE) and number of marketable unhusked ears (NMUE) in the maize crop as a function of cultivars and P levels in the soil

\begin{tabular}{|c|c|c|c|c|c|c|}
\hline \multirow{3}{*}{ Cultivar } & \multicolumn{3}{|c|}{ TNE $h a^{-1}$} & \multicolumn{3}{|c|}{ NMUE $h a^{-1}$} \\
\hline & \multicolumn{3}{|c|}{ Soll P levels } & \multicolumn{3}{|c|}{ Soll P levels } \\
\hline & Low & Medium & High & Low & Medium & High \\
\hline & \multicolumn{6}{|c|}{ Season 1 (March to July, 2017) } \\
\hline Dona Josélia & 28646 cC & $42969 \mathrm{cB}$ & $48177 \mathrm{bA}$ & $24740 \mathrm{bB}$ & 41667 aA & $44271 \mathrm{cA}$ \\
\hline Carrapateira & $16927 \mathrm{eB}$ & $32552 \mathrm{dA}$ & $35156 \mathrm{dA}$ & $16927 \mathrm{cB}$ & 29948 bA & $35156 \mathrm{dA}$ \\
\hline Pontinha & $19531 \mathrm{eB}$ & $42969 \mathrm{cA}$ & $41667 \mathrm{cA}$ & $19531 \mathrm{cB}$ & $40365 \mathrm{aA}$ & $40365 \mathrm{cA}$ \\
\hline Cruzeta & $27344 \mathrm{cB}$ & $50781 \mathrm{bA}$ & $46875 \mathrm{bA}$ & $23438 \mathrm{bB}$ & $44271 \mathrm{aA}$ & $42969 \mathrm{cA}$ \\
\hline Potiguar & $33854 \mathrm{bC}$ & $42969 \mathrm{cB}$ & $55990 \mathrm{aA}$ & 18229 cC & $39063 \mathrm{aB}$ & $52083 \mathrm{bA}$ \\
\hline BRS 2022 & $40365 \mathrm{aB}$ & 55990 aA & $53385 \mathrm{aA}$ & $39063 \mathrm{aB}$ & $41667 \mathrm{aB}$ & $48177 \mathrm{bA}$ \\
\hline Status & $41667 \mathrm{aC}$ & $52083 \mathrm{bB}$ & $58594 \mathrm{aA}$ & 18229 cC & $45573 \mathrm{aB}$ & $58594 \mathrm{aA}$ \\
\hline AG 1051 & $23438 \mathrm{~dB}$ & $53385 a A$ & $54688 \mathrm{aA}$ & 16927 cC & $42969 \mathrm{aB}$ & $49479 \mathrm{bA}$ \\
\hline \multirow[t]{2}{*}{ CV $(\%)$} & & 9.12 & & & 9.95 & \\
\hline & \multicolumn{6}{|c|}{ Season 2 (August to December, 2017) } \\
\hline Dona Josélia & 22135 cB & $44177 \mathrm{bA}$ & $42969 \mathrm{eA}$ & $22135 \mathrm{cB}$ & $41667 \mathrm{bA}$ & $39063 \mathrm{cA}$ \\
\hline Carrapateira & $15625 \mathrm{~dB}$ & $31250 \mathrm{cA}$ & $35156 \mathrm{fA}$ & $15625 \mathrm{~dB}$ & $31250 \mathrm{cA}$ & $35156 \mathrm{dA}$ \\
\hline Pontinha & $29948 \mathrm{bB}$ & $44271 \mathrm{bA}$ & $41667 \mathrm{eA}$ & 29948 bB & $37760 \mathrm{bA}$ & $41667 \mathrm{cA}$ \\
\hline Cruzeta & $28646 \mathrm{bB}$ & 50781 aA & $46875 \mathrm{dA}$ & $28646 \mathrm{bB}$ & $50781 \mathrm{aA}$ & $46875 \mathrm{bA}$ \\
\hline Potiguar & $32552 \mathrm{bC}$ & $41667 \mathrm{bB}$ & $54688 \mathrm{bA}$ & $32552 \mathrm{bC}$ & $41667 \mathrm{bB}$ & $52083 \mathrm{aA}$ \\
\hline BRS 2022 & $39063 \mathrm{aB}$ & $41667 \mathrm{bB}$ & $49479 \mathrm{cA}$ & $39063 \mathrm{aB}$ & $42969 \mathrm{bB}$ & $48177 \mathrm{bA}$ \\
\hline Status & $41667 \mathrm{aC}$ & $52083 a B$ & $59896 \mathrm{aA}$ & 29948 bC & $50781 \mathrm{aB}$ & $57292 \mathrm{aA}$ \\
\hline AG 1051 & $28646 \mathrm{bB}$ & $53385 \mathrm{aA}$ & 54688 bA & 28646 bB & $52083 \mathrm{aA}$ & $54688 \mathrm{aA}$ \\
\hline CV (\%) & & 8.04 & & & 8.56 & \\
\hline
\end{tabular}

Means followed by the same letters, uppercase in the row and lowercase in the column, do not differ by Tukey test at $\mathrm{p} \leq 0.05$ and by Scott-Knot test at $\mathrm{p} \leq 0.05$, respectively

Table 4. Mean values for the number of marketable husked ears (NMHE) and total yield of ears (TYE) in the maize crop as a function of cultivars and P levels in the soil

\begin{tabular}{|c|c|c|c|c|c|c|}
\hline \multirow{3}{*}{ Cultivar } & \multicolumn{3}{|c|}{ NMHE ha' ${ }^{-1}$} & \multicolumn{3}{|c|}{ TYE (kg ha-1) } \\
\hline & \multicolumn{3}{|c|}{ Soil P levels } & \multicolumn{3}{|c|}{ Soll P levels } \\
\hline & Low & Medium & High & Low & Medium & High \\
\hline & \multicolumn{6}{|c|}{ Season 1 (March to July, 2017) } \\
\hline Dona Josélia & $0 \mathrm{aC}$ & $22135 \mathrm{cB}$ & $39063 \mathrm{aA}$ & $2752 \mathrm{aC}$ & 9232 bB & $10121 \mathrm{cA}$ \\
\hline Carrapateira & $0 \mathrm{aB}$ & $14323 \mathrm{dA}$ & $18229 \mathrm{dA}$ & $2719 \mathrm{aB}$ & $7757 \mathrm{cA}$ & $8418 \mathrm{~d} A$ \\
\hline Pontinha & $0 \mathrm{aB}$ & $18229 \mathrm{cA}$ & $18229 \mathrm{dA}$ & $2490 \mathrm{aB}$ & $9139 \mathrm{bA}$ & $9165 \mathrm{~d} A$ \\
\hline Cruzeta & $0 \mathrm{aB}$ & 26042 bA & $23438 \mathrm{cA}$ & $2876 \mathrm{aC}$ & $12185 \mathrm{aB}$ & 13962 aA \\
\hline Potiguar & $0 \mathrm{aB}$ & 28646 bA & 28646 bA & $2549 \mathrm{aC}$ & $9725 \mathrm{bB}$ & $14230 \mathrm{aA}$ \\
\hline BRS 2022 & $0 \mathrm{aC}$ & 19531 cB & 29948 bA & $3177 \mathrm{aC}$ & $11624 \mathrm{aB}$ & $13021 \mathrm{bA}$ \\
\hline Status & $0 \mathrm{aC}$ & $32552 \mathrm{aB}$ & 37760 aA & $2876 a \mathrm{a}$ & 12749 aA & $11818 \mathrm{cA}$ \\
\hline AG 1051 & $0 \mathrm{aB}$ & $32552 \mathrm{aA}$ & 35156 aA & $1426 \mathrm{bC}$ & $10341 \mathrm{bB}$ & $11784 \mathrm{cA}$ \\
\hline \multirow[t]{2}{*}{ CV $(\%)$} & & 17.05 & & & 12.10 & \\
\hline & \multicolumn{6}{|c|}{ Season 2 (August to December, 2017) } \\
\hline Dona Josélia & 5208 bB & $36458 \mathrm{bA}$ & $39063 \mathrm{aA}$ & 3074 bB & $10184 \mathrm{cA}$ & $10424 \mathrm{bA}$ \\
\hline Carrapateira & $6510 \mathrm{bB}$ & $15625 \mathrm{cA}$ & $18229 \mathrm{cA}$ & 3314 bB & $8788 \mathrm{cA}$ & $9060 \mathrm{cA}$ \\
\hline Pontinha & $15625 \mathrm{aB}$ & 33854 bA & 29948 bA & $5884 \mathrm{aB}$ & $10151 \mathrm{cA}$ & $11591 \mathrm{bA}$ \\
\hline Cruzeta & 7813 bC & 32552 bB & $39063 \mathrm{aA}$ & $4995 \mathrm{aB}$ & $13673 \mathrm{aA}$ & 13618 aA \\
\hline Potiguar & $13021 \mathrm{aB}$ & $39063 \mathrm{aA}$ & $40365 \mathrm{aA}$ & $6216 \mathrm{aB}$ & $12901 \mathrm{aA}$ & $14540 \mathrm{aA}$ \\
\hline BRS 2022 & $14323 \mathrm{aC}$ & 33854 bB & $39063 \mathrm{aA}$ & $5962 \mathrm{aB}$ & $11527 \mathrm{bA}$ & 12969 aA \\
\hline Status & $5208 \mathrm{bB}$ & $40365 \mathrm{aA}$ & $39063 \mathrm{aA}$ & $4792 \mathrm{aB}$ & $12875 \mathrm{aA}$ & 12990 aA \\
\hline AG 1051 & $10417 \mathrm{aC}$ & 33854 bB & 39063 aA & $3215 \mathrm{bB}$ & $12117 \mathrm{bA}$ & $12941 \mathrm{aA}$ \\
\hline CV $(\%)$ & & 10.39 & & & 11.13 & \\
\hline
\end{tabular}

Means followed by the same letters, uppercase in the row and lowercase in the column, do not differ by Tukey test at $\mathrm{p} \leq 0.05$ and by Scott-Knot test at $\mathrm{p} \leq 0.05$, respectively

of unhusked ears, husked ears and total. Ribeiro et al. (2016) and Rodrigues et al. (2018) agree that there is an increase in the production of green ears with the increase in P levels.

For the number of marketable unhusked ears (NMUE), the cultivar Status was statistically superior in both seasons, not differing from Potiguar and AG 1051 in Season 2 (Table 3). The cultivar BRS 2022 stood out with respect to NMUE at the low level of $\mathrm{P}$, that is, almost all plants of BRS 2022 produced marketable ears at the minimum level of $\mathrm{P}$, although the result is quite different when the ears are husked.

The cultivars Dona Josélia, Status and AG 1051 had the highest number of marketable husked ears (NMHE) in Season 1. In Season 2, the cultivar Potiguar proved to be better at all
P levels, without differing from Dona Josélia, Cruzeta, BRS 2022, Status and AG 1051 (Table 4). There was no difference between the medium and high levels of $\mathrm{P}$ for most cultivars, with respect to TNE, NMUE and NMHE.

In Season 1, none of the cultivars produced marketable husked ears at the low level of P. Soil P contents in both experimental areas were below the sufficiency level for maize proposed by Malavolta et al. (1997), who suggest $6 \mathrm{mg} \mathrm{dm}^{-3}$ of $\mathrm{P}$ in the superficial layer of $0-10 \mathrm{~cm}$.

However, the available P content in the soil in Season 1, in the 0-20 cm layer, was 20 times lower than that of Season 2, which contributed to the non-occurrence of marketable husked ears at the low level of $\mathrm{P}$ in this season. 
Table 5. Mean values for the yield of marketable unhusked ears (YMUE) and yield of marketable husked ears (YMHE) in the maize crop as a function of cultivars and P levels in the soil

\begin{tabular}{|c|c|c|c|c|c|c|}
\hline \multirow{3}{*}{ Cultivar } & \multicolumn{3}{|c|}{ YMUE (kg ha-1) } & \multicolumn{3}{|c|}{ YMHE (kg ha-1) } \\
\hline & \multicolumn{3}{|c|}{ Soil P levels } & \multicolumn{3}{|c|}{ Soil P levels } \\
\hline & Low & Medium & High & Low & Medium & High \\
\hline & \multicolumn{6}{|c|}{ Season 1 (March to July, 2017) } \\
\hline Dona Josélia & $2372 \mathrm{aB}$ & $10121 \mathrm{bA}$ & $10266 \mathrm{CA}$ & $0 \mathrm{aC}$ & $4919 \mathrm{aB}$ & $6508 \mathrm{aA}$ \\
\hline Carrapateira & $2613 \mathrm{aC}$ & $7757 \mathrm{~dB}$ & $9067 \mathrm{dA}$ & $0 \mathrm{aC}$ & $1422 \mathrm{cB}$ & $3012 \mathrm{cA}$ \\
\hline Pontinha & $2046 \mathrm{bB}$ & $9139 \mathrm{cA}$ & $9165 d A$ & $0 \mathrm{aB}$ & $2068 \mathrm{cB}$ & $4208 \mathrm{bA}$ \\
\hline Cruzeta & $2766 \mathrm{aC}$ & $11402 \mathrm{aB}$ & $13962 a A$ & $0 \mathrm{aB}$ & 4928 aA & $5031 \mathrm{bA}$ \\
\hline Potiguar & $1622 \mathrm{bC}$ & $9725 \mathrm{bB}$ & $13762 \mathrm{aA}$ & $0 \mathrm{aB}$ & 5323 aA & $6227 \mathrm{aA}$ \\
\hline BRS 2022 & $3177 \mathrm{aC}$ & $9706 \mathrm{bB}$ & $12195 \mathrm{bA}$ & $0 \mathrm{aC}$ & $3461 \mathrm{bB}$ & $5397 \mathrm{aA}$ \\
\hline Status & $1798 \mathrm{bB}$ & $12176 \mathrm{aA}$ & $11704 \mathrm{bA}$ & $0 \mathrm{aB}$ & $5970 \mathrm{aA}$ & $6530 \mathrm{aA}$ \\
\hline$A G 1051$ & $910 \mathrm{bC}$ & $9276 \mathrm{cB}$ & $11353 \mathrm{bA}$ & $0 \mathrm{aB}$ & $4532 \mathrm{aB}$ & $6256 \mathrm{aA}$ \\
\hline \multirow[t]{2}{*}{ CV (\%) } & & 13.51 & & & 25.92 & \\
\hline & \multicolumn{6}{|c|}{ Season 2 (August to December, 2017) } \\
\hline Dona Josélia & $3074 \mathrm{bB}$ & $10184 \mathrm{bA}$ & $10424 \mathrm{bA}$ & $378 \mathrm{bC}$ & $5271 \mathrm{bB}$ & $6892 \mathrm{bA}$ \\
\hline Carrapateira & $3314 \mathrm{bB}$ & 8788 bA & $9460 \mathrm{bA}$ & $689 \mathrm{bB}$ & $2960 \mathrm{cA}$ & $3169 \mathrm{cA}$ \\
\hline Pontinha & $5796 \mathrm{aB}$ & $10151 \mathrm{bA}$ & $11591 \mathrm{aA}$ & $2605 \mathrm{aB}$ & 5991 bA & $6102 \mathrm{bA}$ \\
\hline Cruzeta & $4878 \mathrm{aB}$ & 13673 aA & $13618 \mathrm{aA}$ & 1017 bB & $6172 \mathrm{bA}$ & $7335 \mathrm{aA}$ \\
\hline Potiguar & $5992 \mathrm{aB}$ & $12901 \mathrm{aA}$ & $12302 \mathrm{aA}$ & $1754 \mathrm{aB}$ & $7690 \mathrm{aA}$ & $8393 \mathrm{aA}$ \\
\hline BRS 2022 & $5895 \mathrm{aC}$ & $9840 \mathrm{bB}$ & $12473 \mathrm{aA}$ & $1884 \mathrm{aB}$ & 5625 bA & $6595 \mathrm{bA}$ \\
\hline Status & $3901 \mathrm{bC}$ & 10549 bB & $12875 \mathrm{aA}$ & $749 \mathrm{bB}$ & $7967 \mathrm{aA}$ & $7367 \mathrm{aA}$ \\
\hline AG 1051 & $3215 \mathrm{bB}$ & 12117 aA & $12941 \mathrm{aA}$ & $813 \mathrm{bB}$ & $6900 \mathrm{aA}$ & $8005 \mathrm{aA}$ \\
\hline CV (\%) & & 12.82 & & & 17.89 & \\
\hline
\end{tabular}

Means followed by the same letters, uppercase in the row and lowercase in the column, do not differ by Tukey test at $\mathrm{p} \leq 0.05$ and by Scott-Knot test at $\mathrm{p} \leq 0.05$, respectively

In the rainy period, there was a higher incidence of pests in the area of Season 1, especially in the environment without $\mathrm{P}$ application. In addition, the month of March, planting period in Season 1, concentrated the largest amount of rains of the year (Table 2), which may have washed some nutrients from the profile, mainly the nitrogen applied as basal fertilization.

The conditions described above also contributed to the absence of marketable husked ears, as well as to the lower production of ears at the low level of $\mathrm{P}$ in Season 1.

The cultivars Cruzeta and Potiguar differed statistically from the others, with the highest values of total yield of ears (TYE) in Season 1. For Season 2, Cruzeta, Potiguar and Status were the best at all doses, followed by BRS 2022 and AG 1051. The cultivars did not differ statistically between the medium and high levels of $\mathrm{P}$ in Season 2 (Table 4).

In relation to the yield of marketable unhusked ears (YMUE), the cultivars Cruzeta and Potiguar showed higher values at the high level of $\mathrm{P}$ in Season 1. In Season 2, Cruzeta stood out at all levels of P, followed by AG 1051, Status, BRS 2022, Potiguar and Pontinha. There was difference between the medium and high levels of $\mathrm{P}$ in Season 2 only for the cultivars BRS 2022 and Status (Table 5).

For the yield of marketable husked ears (YMHE), Dona Josélia, Status, AG 1051, Potiguar and BRS 2022 were better in Season 1, under the high level of P. Among these, only BRS 2022 differed statistically at the medium level of P.

In Season 2, the cultivars Potiguar, AG 1051, Status and Cruzeta had higher values. Except for Dona Josélia, the cultivars did not differ between the medium and high levels of $\mathrm{P}$ in Season 2 (Table 5).

In general, the variables TYE, YMUE and YMHE were higher in Season 2 than in Season 1, especially at the low level of $\mathrm{P}$ (Tables 4 and 5). Besides the higher $\mathrm{P}$ content in the area of Season 2, another relevant factor is the global solar radiation along this season, which was much higher (Table 2), especially in October, the period of ear filling.
The maximum use of radiation occurs in pre-flowering and grain filling, which represent the most critical period (Rosa et al., 2017). The effect of radiation is also responsible for the similarity of values between the medium and high levels of $\mathrm{P}$ for TYE, YMUE and YMHE in Season 2. Thus, a lower level of $P$ can be used and, despite that, a large amount of green ears can be obtained.

The good performance of Cruzeta and Potiguar in terms of TYE, YMUE and YMHE is due to the fact that these cultivars are adapted to the region where the experiments were conducted, with excellent characteristics of adaptability to the northeastern climate and good production stability, being able to express all their production potential.

AG 1051 also stood out with respect to these variables, which was expected given the purpose of use of this cultivar, which is production of green ears, besides being recommended for the climatic conditions of the area where the experiments were installed. Status was another relevant cultivar in the present study, due to its good production stability and wide adaptation to the management adopted.

It is worth pointing out that the above-mentioned cultivars were highly responsive to the use of $\mathrm{P}$, with significant increases in the production of green ears and, whatever the purpose, production of either unhusked or husked ears, the experiment conducted in the dry period (Season 2) showed better results than that conducted in the rainy period (Season 1), especially in relation to the production of marketable husked ears.

In both seasons, regarding the indices of nutritional efficiency, there was a significant difference between cultivars for all efficiency indices evaluated, whose means can be observed in Table 6.

The cultivars Cruzeta, Potiguar, BRS 2022 and AG 1051 showed higher agronomic efficiency (AE) in Season 1. Thus, for each $\mathrm{kg}$ of $\mathrm{P}_{2} \mathrm{O}_{5}$ applied to the soil, these cultivars produced $138.57,146.01,123.05$ and $129.47 \mathrm{~kg}$ of green ears, respectively. In Season 2, AG 1051, Cruzeta, Potiguar and Status were the most efficient cultivars (Table 6). 
Table 6. Mean values for agronomic efficiency (AE), physiological efficiency (PE), ear production efficiency (EPE), recovery efficiency (RE) and utilization efficiency (UE) in maize crop

\begin{tabular}{lccccc}
\hline \multirow{2}{*}{ Cultivar } & AE & PE & EPE & RE & UE \\
\cline { 2 - 6 } & \multicolumn{5}{c}{$\left(\mathbf{k g ~ k g}^{-1}\right)$} \\
Dona Josélia & $92.11 \mathrm{~b}$ & $478.46 \mathrm{~d}$ & $440.94 \mathrm{c}$ & $0.21 \mathrm{e}$ & $100.26 \mathrm{f}$ \\
Carrapateira & $71.24 \mathrm{c}$ & $431.14 \mathrm{e}$ & $187.62 \mathrm{e}$ & $0.38 \mathrm{a}$ & $163.59 \mathrm{a}$ \\
Pontinha & $83.44 \mathrm{c}$ & $425.23 \mathrm{e}$ & $333.09 \mathrm{~d}$ & $0.25 \mathrm{c}$ & $106.47 \mathrm{e}$ \\
Cruzeta & $138.57 \mathrm{a}$ & $609.75 \mathrm{~b}$ & $659.61 \mathrm{a}$ & $0.22 \mathrm{e}$ & $128.39 \mathrm{c}$ \\
Potiguar & $146.01 \mathrm{a}$ & $491.20 \mathrm{~d}$ & $672.49 \mathrm{a}$ & $0.22 \mathrm{e}$ & $106.58 \mathrm{e}$ \\
BRS 2022 & $123.05 \mathrm{a}$ & $685.66 \mathrm{a}$ & $741.94 \mathrm{a}$ & $0.17 \mathrm{f}$ & $113.51 \mathrm{~d}$ \\
Status & $111.77 \mathrm{~b}$ & $499.22 \mathrm{~d}$ & $424.98 \mathrm{c}$ & $0.26 \mathrm{~b}$ & $131.15 \mathrm{c}$ \\
AG 1051 & $129.47 \mathrm{a}$ & $588.13 \mathrm{c}$ & $566.68 \mathrm{~b}$ & $0.23 \mathrm{~d}$ & $134.37 \mathrm{~b}$ \\
CV (\%) & 22.51 & 12.44 & 23.47 & 14.59 & 15.42 \\
\hline \multicolumn{5}{c}{ Season 2 (August to December, 2017) } \\
Dona Josélia & $91.88 \mathrm{~b}$ & $444.47 \mathrm{~b}$ & $573.95 \mathrm{a}$ & $0.16 \mathrm{c}$ & $71.29 \mathrm{~b}$ \\
Carrapateira & $71.83 \mathrm{~b}$ & $415.60 \mathrm{c}$ & $212.18 \mathrm{c}$ & $0.34 \mathrm{a}$ & $140.18 \mathrm{a}$ \\
Pontinha & $71.34 \mathrm{~b}$ & $443.70 \mathrm{~b}$ & $401.05 \mathrm{~b}$ & $0.18 \mathrm{~b}$ & $78.59 \mathrm{~b}$ \\
Cruzeta & $107.80 \mathrm{a}$ & $402.64 \mathrm{c}$ & $595.11 \mathrm{a}$ & $0.18 \mathrm{~b}$ & $73.38 \mathrm{~b}$ \\
Potiguar & $104.05 \mathrm{a}$ & $456.54 \mathrm{~b}$ & $621.63 \mathrm{a}$ & $0.17 \mathrm{c}$ & $76.31 \mathrm{~b}$ \\
BRS 2022 & $87.58 \mathrm{~b}$ & $473.14 \mathrm{~b}$ & $520.26 \mathrm{a}$ & $0.17 \mathrm{c}$ & $79.53 \mathrm{~b}$ \\
Status & $101.04 \mathrm{a}$ & $556.34 \mathrm{a}$ & $677.78 \mathrm{a}$ & $0.15 \mathrm{c}$ & $82.89 \mathrm{~b}$ \\
AG 1051 & $121.58 \mathrm{a}$ & $413.89 \mathrm{c}$ & $671.71 \mathrm{a}$ & $0.18 \mathrm{~b}$ & $75.29 \mathrm{~b}$ \\
CV (\%) & 19.11 & 14.24 & 21.63 & 15.31 & 16.59 \\
\hline
\end{tabular}

Means followed by the same letter do not differ by Scott-Knot test at $p \leq 0.05$

It is worth remembering that, in order to obtain high yields, the recommended quantity does not always correspond to the same quantity that promotes gains in agronomic efficiency, so agronomic efficiency may decrease as a function of P levels, because the supply of $\mathrm{P}$ exceeds the needs of the crop (law of diminishing returns).

For physiological efficiency (PE), the cultivar BRS 2022 showed higher value in Season 1, when for each $\mathrm{kg}$ of accumulated $\mathrm{P}$, the plant produced $685.66 \mathrm{~kg}$ of dry matter (Table 6). In Season 2, Status stood out from the others, producing $556.34 \mathrm{~kg}$ of dry matter per $\mathrm{kg}$ of accumulated P. It can be said that these cultivars were the most efficient in the absorption and conversion of $\mathrm{P}$ to dry matter production.

In relation to ear production efficiency (EPE), which indicates the efficiency of the cultivar in converting $\mathrm{P}$ for the production of ears, Cruzeta, Potiguar and BRS 2022 reached the highest values in Season 1.

In Season 2, Status showed the highest value, without differing statistically from AG 1051, Potiguar, Cruzeta, Dona Josélia and BRS 2022 (Table 6). It can be inferred that these cultivars were the most efficient in the processes associated with the absorption, assimilation and redistribution of $\mathrm{P}$ in the plant.

For recovery efficiency (RE), amount of nutrient accumulated per unit of nutrient applied, the cultivar Carrapateira had the highest value in both seasons (Table 6). This result was already expected, because Carrapateira was the cultivar that had the highest $\mathrm{P}$ accumulation in both seasons.

However, this cultivar did not show the best values of agronomic efficiency or ear production efficiency, that is, there was greater contribution of leaves and stems in $\mathrm{P}$ partition to the detriment of the ears.

The greater amplitude in $\mathrm{P}$ accumulation between the low and high levels of P, i.e., very low accumulations at the minimum level and high accumulation at the maximum level of $\mathrm{P}$, contributed to the higher recovery efficiency of the cultivars in Season 1.

Regarding the use efficiency (UE), Carrapateira was the best in both seasons, because of the higher RE of this cultivar, since UE corresponds to the product of physiological efficiency and recovery efficiency (Table 6). Here also, the values of Season 1 were higher than those of Season 2, being directly influenced by the greater difference between $\mathrm{P}$ accumulations at low and high levels of $\mathrm{P}$.

The good performance of the cultivar Carrapateira in terms of UE is due to its higher mass and volume of roots, which contributes to the greater absorption and accumulation of $\mathrm{P}$. DoVale et al. (2013) agree that the large volume of roots in maize plants favors $P$ use efficiency.

Other authors (Bayuelo-Jiménez \& Ochoa-Cadavid, 2014; Pelá et al., 2017; Spolaor et al., 2018) argue that there are variations among maize cultivars regarding $\mathrm{P}$ use efficiency, which was observed in the present study. In this context, the cultivar Carrapateira has great potential to be explored in breeding programs aiming at $\mathrm{P}$ use efficiency.

\section{Conclusions}

1. The cultivars showed better production performance when fertilized with phosphorus.

2. The cultivars Cruzeta, Potiguar, BRS 2022, Status, AG 1051 and Carrapateira were the most efficient ones in the use of phosphorus for the production of green maize.

\section{Literature Cited}

Bayuelo-Jiménez, J. S.; Ochoa-Cadavid, I. Phosphorus acquisition and internal utilization efficiency among maize landraces from the central Mexican highlands. Field Crops Research, v.156, p.123134, 2014. https://doi.org/10.1016/j.fcr.2013.11.005

Carmo Filho, F.; Oliveira, O. F. Mossoró: Um município do semi-árido nordestino, caracterização climática e aspecto florístico. Mossoró: ESAM, 1995. 62p.

Cavalcanti, F. J. de A. (coord.). Recomendações de adubacão para o Estado de Pernambuco: 2. aproximação. Recife: Instituto Agronômico de Pernambuco, 2008. 212p.

Colombo, G. A.; Vaz-de-Melo, A.; Souza, A. S. de; Silva, J. G. C. Capacidade combinatória de híbridos de milho para eficiência e resposta ao uso do fósforo. Revista Agrogeoambiental, v. 10, p.47-60, 2018. https://doi.org/10.18406/2316$1817 \mathrm{v} 10 \mathrm{n} 220181088$

Corrêa Junior, D.; Garcia, R. F.; Manhães, C. M. C.; Klaver, P. P. C.; Vale, W. G. do; Gravina, G. de A. Influência da adubação de plantio na produtividade do milho verde. Global Science and Technology, v.7, p.12-18, 2014. https://doi.org/10.14688/19843801/gst.v7n3p12-18

Couto, C. A. do; Silva, E. M. da; Silva, A. G. da; Oliveira, M. T. P.; Vasconcelos, J. C. de; Silva, A. R. da; Sobreira, E. de A.; Moura, J. B. de. Desempenho de cultivares de milho destinados para produção de milho verde e silagemal. Fronteiras: Journal of Social, Technological and Environmental Science, v.6, p.232-251, 2017. https://doi.org/10.21664/2238-8869.2017v6i1.p232-251 
DoVale, J. C.; Maia C.; Fritsche-Neto, R.; Miranda, G. V.; Cavatte, P. C. Genetic responses of traits relationship to components of nitrogen and phosphorus use efficiency in maize. Acta Scientiarum. Agronomy, v.35, p.31-38, 2013. https://doi.org/10.4025/ actasciagron.v35i1.15237

Fageria, N. K. The use of nutrients in crop plants. 1.ed. Boca Raton: CRC Press, 2008. 448p.

Ferreira, D. F. Sisvar: A computer statistical analysis system. Ciência e Agrotecnologia, v.35, p.1039-1042, 2011. https://doi.org/10.1590/ S1413-70542011000600001

Gazola, R. de N.; Buzetti, S.; Dinalli, R. P.; Teixeira Filho, M. C. M.; Celestrino, T. de S. Efeito residual da aplicação de fosfato monoamônio revestido por diferentes polímeros na cultura de milho. Revista Ceres, v.60, p.876-884, 2013. https://doi. org/10.1590/S0034-737X2013000600016

Klein, C.; Agne, S. A. A. Fósforo: de nutriente a poluente. Revista Eletrônica em Gestão, Educação e Tecnologia Ambiental, v.8, p.1713-1721, 2012. https://doi.org/10.5902/223611706430

Machado, V. J.; Souza, C. H. E. de. Disponibilidade de fósforo em solos com diferentes texturas após aplicação de doses crescentes de fosfato monoamônico de liberação lenta. Bioscience Journal, v.28, p.1-7, 2012.

Malavolta, E.; Vitti, G. C.; Oliveira, S. A. Avaliação do estado nutricional das plantas. Princípios e aplicações. 2.ed. Piracicaba: Potafos, 1997. 319p.

Meirelles, W. F.; Parentoni, S. N.; Guimarães, L. J. M.; Guimarães, P. E. de O.; Pacheco, C. A. P.; Oliveira, A. C. de; Mendes, F. F.; Scapim, C. A. Análise dialélica de linhagens de milho quanto à responsividade ao fósforo e à sua eficiência de uso. Pesquisa Agropecuária Brasileira, v.51, p.224-232, 2016. https://doi. org/10.1590/S0100-204X2016000300004

Mendes, F. F.; Guimarães, L. J. M.; Souza, J. C.; Guimarães, P. E. O.; Magalhães, J. V.; Garcia, A. A. F.; Parentoni, S. N.; Guimarães, C. T. Genetic architecture of phosphorus use efficiency in tropical maize cultivated in a low P soil. Crop Science, v.54, p.1530-1538, 2014. https://doi.org/10.2135/cropsci2013.11.0755
Oliveira, M. A. de; Zucareli, C.; Ferreira, A. S.; Domingues, A. R.; Spolaor, L. T.; Neves, C. S. V. J. Adubação fosfatada associada à inoculação com Pseudomonas fluorescens no desempenho agronómico do milho. Revista de Ciências Agrárias, v.38, p.1825, 2015.

Paiva, M. R. de F. C.; Silva, G. F. da; Oliveira, F. H. T. de; Pereira, R. G.; Queiroga, F. M. de. Doses de nitrogênio e de fósforo recomendadas para produção econômica de milho-verde na Chapada do ApodiRN. Revista Caatinga, v.25, p.1-10, 2012.

Pelá, A.; Gonçalves, R. N.; Pereira, F. de S.; Rodrigues, F.; Cruz, S. J. S. Phosphorus use efficiency in maize as a function of different sources. Australian Journal of Crop Science, v.11, p.71-75, 2017. https://doi.org/10.21475/ajcs.2017.11.01.236

Ribeiro, M. C.; Damaso, L. F.; Costa, F. R.; Pelá, A.; Rodrigues, F. Híbridos de milho sob diferentes doses de fósforo visando o consumo in natura. Magistra, v.28, p.273-278, 2016.

Rodrigues, F.; Melo, P. G. S.; Resende, C. L. P.; Mrojinski, F.; Mendes, R. C.; Silva, M. A. Aptidão de híbridos de milho para o consumo in natura. Revista de Ciências Agrárias, v.41, p.484-492, 2018. https://doi.org/10.19084/RCA17216

Rosa, A. P. S. A. da; Emygdio, B. M.; Bispo, N. B. Indicações técnicas para o cultivo do milho e do sorgo no Rio Grande do Sul: Safras 2017/2018 e 2018/2019. 1.ed. Passo Fundo: Embrapa Trigo, 2017. 209p.

Sousa, S. M. de; Clark, R. T.; Mendes, F. F.; Oliveira, A. C. de; Vasconcelos, M. J. V. de; Parentoni, S. N.; Kochian, L. V.; Guimarães, C. T.; Magalhães, J. V. A role for root morphology and related candidate genes in $\mathrm{P}$ acquisition efficiency in maize. Functional Plant Biology, v.39, p.925-935, 2012. https://doi. org/10.1071/FP12022

Spolaor, L. T.; Guirado, G. C.; Scapim, C. A.; Kuki, M. C.; Bertagna, F. A. B.; Ferreira, J. M.; Zucareli, C.; Gonçalves, L. S. A. Brazilian maize landraces variability under high and low phosphorus inputs. Maydica Electronic Publication, v.63, p.1-8, 2018.

USGS - United States Geological Survey. Mineral commodity summaries 2019. Virgínia: USGS, 2019. 200p. 